\title{
What an introduced species can tell us about the spatial extension of benthic populations
}

\author{
Werner Armonies* \\ Alfred-Wegener-Institut für Polar- und Meeresforschung, Biologische Anstalt Helgoland, Wattenmeerstation Sylt, 25992 List, Germany
}

\begin{abstract}
In the late 1970s the American jackknife Ensis americanus (syn. E. directus) was introduced into the North Sea. The history of its dispersal along the coast is used to derive an estimate of the species' mobility. On average, the population spread by $125 \mathrm{~km}$ per year to the north and, at the same time, by $75 \mathrm{~km}$ per year to the west, against the residual currents. Therefore, recruitment in a given area may depend on larvae produced some $125 \mathrm{~km}$ upstream while the offspring produced in the study area may recruit another $125 \mathrm{~km}$ downstream. As a consequence, the population dynamics cannot be explained from single-site sampling and even studies on local effects need knowledge of the population dynamics on a large spatial scale to distinguish between general trends and local peculiarities. For E. americanus in the North Sea a minimum longshore extension of the sampling area of some $250 \mathrm{~km}$ is suggested. Provided other benthic species with pelagic larvae have similar dispersal capabilities, community studies need a similar spatial scale. This implies that the number of distinguishable major communities is very limited in the coastal North Sea. To overcome the logistic difficulties in studying a sufficiently large area, a permanent network of institutes engaged in benthic population and community dynamics is recommended.
\end{abstract}

KEY WORDS: Benthos - Population dynamics $\cdot$ Population structure $\cdot$ Spatial scale $\cdot$ North Sea

Resale or republication not permitted

without written consent of the publisher

Population studies on benthic species in sedimentary environments have been performed for a long period of time (e.g., Möbius 1877). Nevertheless, there is nearly no information about the spatial scales that need to be sampled to obtain reliable estimates of population parameters. Usually, samples are collected somewhere in the (presumed) centre of a population. However, this can only adequately reflect the population composition if the age stages and sexes are uniformly distributed. Particularly in species dispersing by planktonic larvae the spatial patches of juveniles may

*E-mail: warmonies@awi-bremerhaven.de often deviate from those of adults, resulting in habitat partitioning among age groups. Examples are all marine species that have nursery areas, e.g., the bivalves Chlamys opercularis (Cadée 1968) and Macoma balthica (Beukema 1993), lugworms Arenicola marina (Flach \& Beukema 1994), shrimps Crangon crangon (Janssen \& Kuipers 1980), and bottom-feeding fish such as Pleuronectes platessa (Kuipers 1977). In these cases, sampling needs to cover the entire area occupied by any age group, otherwise the population estimates only reflect the situation in the sampled site and not the state of the population. In addition, since the spatial distribution of a population may vary over time, the entire range of habitats that potentially may be occupied needs to be included in sampling.

The dimensions of the area used by a population depends on the mobility of individuals. The term 'mobility' includes the dispersal capabilities of larvae and later stages as well as passive redistribution of benthic stages. The latter may occur from resuspension during sediment disturbance with consecutive transport of the organisms by the currents (e.g., Thiébaut et al. 1996, Olivier \& Retière 1998, Armonies 2000). Adequate scaling of the study area relative to the mobility of species also turned out to be decisive for the detection of density-dependent processes in populations (Ray \& Hastings 1996, Young \& Ebert 1996).

Unfortunately our knowledge of the mobility of specimens is very limited, although it might also indicate the kind of population structure we have to expect. If mobility is rather low, the specimens are most likely organised in separate populations, with a very limited exchange of organisms among them. Increasing mobility will lead to increasing exchange of organisms among the sub-populations of a metapopulation (Hanski 1999). Finally, high mobility may be indicative of a population distributed across a large area, and a patchy distribution within this area (Thomas \& Kunin 
1999). Usually, such patchiness may reflect resource heterogeneity, disturbances, or the capacity for reaching all suitable sites.

As a rare exception in marine invertebrates, there is some information about the mobility of razor clams Ensis americanus (Binney, 1870). This species is a wellknown inhabitant of the lower intertidal and shallow subtidal along the entire North American Atlantic coast between Labrador and Florida (Theroux \& Wigley 1983). In the late 1970s it was introduced into the North Sea, presumably as larvae in the ballast water of a ship crossing the Atlantic (Von Cosel et al. 1982). Analysing the history of its dispersal along the coastal North Sea gives an idea of its mobility. In this species, development includes a planktonic larva, and duration of the planktonic larval phase is 10 to $29 \mathrm{~d}$, depending on temperature (Loosanov \& Davies 1963). This is within the range of 2 to $6 \mathrm{wk}$ assumed typical for completion of planktonic larval development in temperate invertebrates (Thorson 1961, Scheltema 1986). Postlarval specimens up to $55 \mathrm{~mm}$ shell length are capable of byssus-drifting (Essink 1985, and references therein). On the other hand, like other Ensis species $E$. americanus has an excellent burying capacity (Swennen et al. 1985, Schiedek \& Zebe 1987). Therefore, it may not be very susceptible to passive dislocation during sediment disturbance and the dispersal capabilities of E. americanus may be amidst the range of other macrobenthic species in the North Sea with a pelagic larval phase. Similar dispersal capabilities of benthic

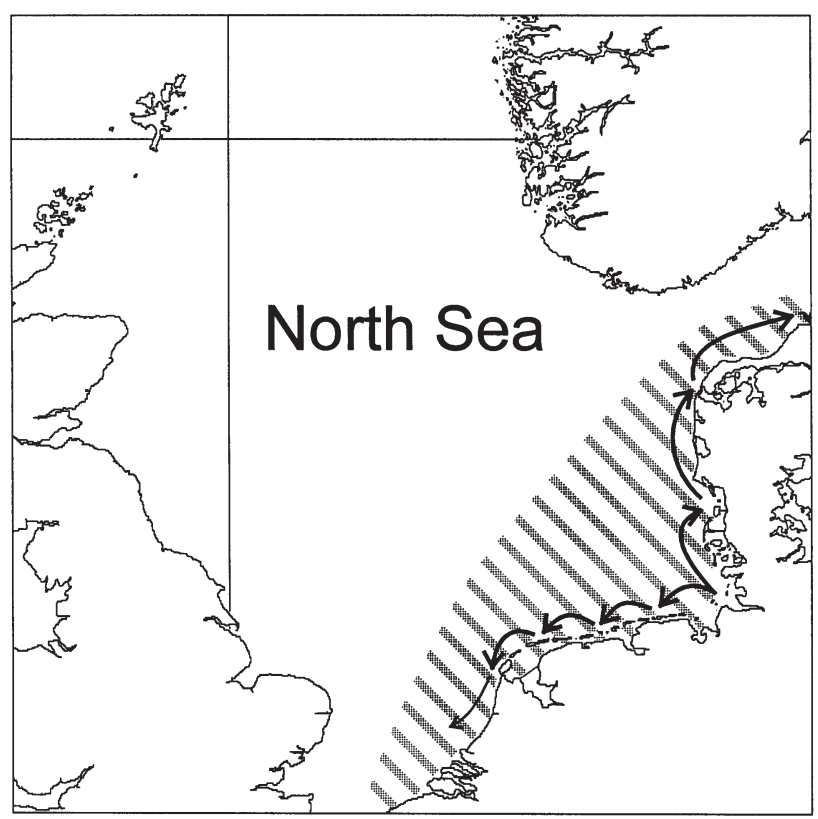

Fig. 1. Ensis americanus. Presumed annual stages of clam dispersal in the North Sea (arrows) and the potential dimension of a 'coastal continental benthic community' (hatched area) species with pelagic larvae are expected for other shelf sea areas (e.g., Mileikovsky 1968, Scheltema 1986) though modulated by the velocity of local currents.

Dispersal of Ensis americanus along the coastal North Sea. In the North Sea, a first population of 1 yr old specimens was found in 1979 at the mouth of the River Elbe estuary (Von Cosel et al. 1982). The species rapidly spread along the continental coastline of the North Sea, presumably as pelagic larvae and byssus-drifting postlarvae. Local studies on age composition indicated that Ensis americanus had reached the island of Sylt (about $125 \mathrm{~km}$ from the first findings) in 1979, and by 1982 it had passed the Skagerrak area (about $500 \mathrm{~km}$ from the first findings; Essink 1985, 1986). This equals an average dispersal of $125 \mathrm{~km} \mathrm{yr}^{-1}$ in the northward direction, i.e., with the residual currents of the eastern North Sea. In the westward direction dispersal was against the residual currents. Nevertheless, E. americanus had reached the Ems estuary by 1981 and the island of Texel $(300 \mathrm{~km}$ from the first findings) no later than 1982 (Essink 1985, 1986). This equals an average dispersal of $75 \mathrm{~km} \mathrm{yr}^{-1}$ (Fig. 1). In the case that Von Cosel et al. (1982) had actually missed 1 yr of study, i.e., the species had already been introduced into the North Sea in 1977, the estimated average dispersal rates of E. americanus would be less (ca $100 \mathrm{~km}$ northwards and $60 \mathrm{~km}$ towards the west). The temporal course of dispersal along the coastline fits the hypothesis of a single introduction of E. americanus into the North Sea but cannot exclude the possibility of multiple imports of the species. This may be tested by genetic analyses.

In the coastal North Sea, the direction and velocity of the currents are highly variable. Daily average velocities between 0.02 and $0.1 \mathrm{~m} \mathrm{~s}^{-1}$ (i.e., 1.7 to $8.6 \mathrm{~km} \mathrm{~d}^{-1}$ ) are common while stormy weather may increase the current velocities up to $0.3 \mathrm{~m} \mathrm{~s}^{-1}$ (roughly $25 \mathrm{~km} \mathrm{~d}^{-1}$; BSH 2000, Dick pers. comm.). Therefore, the observed annual dispersal of 125 or $75 \mathrm{~km}$ may be well explained by a $20 \mathrm{~d}$ duration of the larval phase and rather calm weather, or by a few days with stormy weather, which results in faster currents. In addition, Ensis americanus is capable of secondary dispersal by byssus-drifting, as may be generally the case in bivalves (Sigurdsson et al. 1976). Byssus-drifting $E$. americanus were about 7 times more abundant in the water column during night than during daylight (Armonies 1992), indicating that they performed vertical migrations between the sediment and the water column. This may result in unidirectional transport over much larger spatial scales than is expected for non-migrating particles in tidal waters (Hill 1991).

Highest abundances were recorded between midintertidal and shallow subtidal areas, often in a rather mobile sediment (Beukema \& Dekker 1995, Armonies \& Reise 1999). Byssus-drifting specimens were also 
abundant in the water column above upper intertidal sediments but the specimens did not permanently settle there (Armonies 1998). The deepest locality of Ensis americanus so far encountered in the North Sea is $26 \mathrm{~m}$ (Mühlenhardt-Siegel et al. 1983, but see Niermann 1997 for occurrence of Ensis sp. at $39 \mathrm{~m}$ depth). However, along the US Atlantic coast this species can occur down to $100 \mathrm{~m}$ depth (Theroux \& Wigley 1983). Thus, $E$. americanus has the potential to occupy the entire German Bight in the North Sea unless the combination of reduced oxygen concentration in the bottom water layer (Hickel et al. 1989) and the clam's limited tolerance to hypoxia (Schiedek \& Zebe 1987) restrict it to the shallow coastal zone without a thermohaline stratification.

Conclusions for macrobenthic population studies. In order to understand (and in the long run, predict) local population dynamics of Ensis americanus, information is needed on the number of offspring produced up to $125 \mathrm{~km}$ in an upstream direction and $75 \mathrm{~km}$ in a downstream direction because this may determine the larval supply to the locality under interest. This means that a local reduction of larval production may result in low recruitment somewhere up to $125 \mathrm{~km}$ away, thus spatially separating causes and consequences. The offspring of a studied locality, in turn, may recruit somewhere between $75 \mathrm{~km}$ upstream and $125 \mathrm{~km}$ downstream. Combining both ranges, we arrive at a longshore range of some $250 \mathrm{~km}$ of coastline. According to the currently known bathymetric distribution, the studied area should expand between mid-tide level and ca $30 \mathrm{~m}$ depth, which is equivalent to about $60 \mathrm{~km}$ in the continental North Sea. Thus, an adequately scaled study on the population dynamics of $E$. americanus in the North Sea needs a sampling area of about $15000 \mathrm{~km}^{2}$ (or $12000 \mathrm{~km}^{2}$ if the species was already introduced in 1977).

Ensis americanus was not selected as an example because of its outstanding dispersal capabilities, but its introduction simply represented an unintended, largescale experiment on dispersal. Though factors like the time of reproduction, rate of development, patterns of vertical migration, and seasonal changes in the velocity and direction of the currents may add substantial variability to the horizontal transport of larvae (Scheltema 1986), similar spatial scales are expected to be appropriate for population studies on other macrobenthic species with planktonic larvae. A recent example is the spread of the mussel Mytilus galloprovincialis invading coastal waters in South Africa, which showed a yearly increase in the range of 55 to $97 \mathrm{~km}$ to the northeast and 12 to $29 \mathrm{~km}$ to the southwest (McQuaid \& Phillips 2000). On the other hand, a much smaller area (possibly tens of $\mathrm{km}$ ) may suffice for population studies on species with a short planktonic larval phase.
Effects on community studies. In studies on a community level, adequate scaling may be of similar importance because community features such as numerical abundance or biomass are often strongly dominated by a few species, at least in temperate zones. Particularly when dealing with 'major communities' ('communities that are of a sufficient size and completeness of organisation that they are relatively independent; that is, they need only to receive sun energy from the outside and are relatively independent of inputs and outputs from adjacent communities'; Odum 1971, p. 140), inadequately sizing the study area relative to the mobility of the dominant species would result in unreliable estimates for the entire community dynamics.

Community studies often aim to detect temporal changes in community composition. If the studied area is small relative to the mobility of the specimens there is no way to find out if a detected change really indicates a temporal change in the community, or a spatial shift of some members of the community. The Ensis americanus example demonstrates that such a spatial shift may easily cover a distance of tens of $\mathrm{km}$, at least in species with planktonic larvae. As a rule of thumb I propose that the minimum extension of the study area should enclose the annual dispersal capability of the dominant species in either direction. Since E. americanus may be a dominant species in the benthos of the entire continental coastal North Sea (M. Strasser pers. comm.), it is concluded that community studies also demand for a minimum longshore extension in the range of $250 \mathrm{~km}$.

Long-distance dispersal of benthic species with planktonic larvae should result in a high degree of similarity of the benthic fauna in the continental North Sea. This was indeed observed during North Sea-wide comparisons (e.g., Glémarec 1973, Dyer et al. 1983, Adams 1987, Basford \& Eleftheriou 1988, Künitzer et al. 1992; Fig. 1) and was explained by similar environmental conditions within this area (e.g., a high seasonal variability of temperature compared to other parts of the North Sea). Wide ranges of dispersal of benthic species provide another (though not necessarily alternative) explanation. In addition, dispersal may contribute to the spatial synchrony in population dynamics over large spatial scales (e.g., Beukema \& Essink 1986, Beukema et al. 1988, 1996) although the effects of environmental correlation and dispersal may not be purely additive (Kendall et al. 2000).

Thus, the entire 'coastal continental North Sea' may be inhabited by a single major benthic community stretching over several hundreds of $\mathrm{km}$, with some local variations of species composition according to sediment types (Salzwedel et al. 1985). This is not an unlikely spatial scale. Studying the continental shelf 
area west of Norway, Mileikovsky (1968) argued that rather constant exports of larvae from the continental shelf may lead to the formation of bathyal and abyssal 'pseudopopulations' 100 to 500 miles offshore that can only exist permanently by being regularly replenished by larvae settling out of the surface current. For the crab Cancer magister in the California current the spatial scale of dispersal was estimated to be roughly 100 to $200 \mathrm{~km}$ (Botsford et al. 1998). On the other hand, Gaylord \& Gaines (2000) suggested that the colliding areas of nearshore ocean currents have the potential to constrain a species' geographic range even when suitable habitat outside this range is abundant. Besides the rather continuous latitudinal changes of community composition, such currents might delimit the 'continental North Sea' benthos community in the English Channel, i.e., at its southern limit, and at the same time at its northern limit in the Skagerrak area.

Because of the high variability of currents in the coastal North Sea (BSH 2000) benthic species with planktonic larvae are unlikely to exist in spatially isolated populations. This may only be expected under particular hydrographic conditions (e.g., Verdier-Bonnet et al. 1997) or in species confined to estuaries that are unable to survive current-driven transport across a fully marine area. Instead, in many species mobility may be high enough for more or less regular exchange of organisms between local (sub-) populations connecting a metapopulation complex. Hanski (1999) stated that if all local populations have a substantial risk of local extinction, long-term survival is possible only at the metapopulation level. In the coastal North Sea, a 'substantial risk of local extinction' may derive from the high variability of the environment, with gales disturbing vast areas, a long lasting ice-cover during cold winters in onshore areas, or oxygen depletion below stratified waters during warm summers in offshore areas. Thus, the variability of the environment may select for species with a high mobility, hence a high capacity for colonisation of disturbed areas. In some species with a very high mobility the entire continental North Sea may even represent the distributional area of a single population with a patchy distribution according to environmental heterogeneity. In conclusion, studies on benthic community dynamics in the coastal North Sea should be carried out on a spatial scale no less than $250 \mathrm{~km}$ across.

Recommendations for future research. Certainly the above estimates of the dispersal capacity in Ensis americanus bear some sources of error, e.g., deriving from the limited number of sites that were available for reconstruction of dispersal or the general problem to record a species when abundance is low. However, the velocity of the tidal currents in the coastal North Sea (commonly 1.7 to $8.6 \mathrm{~km} \mathrm{~d}^{-1}$ during calm weather; $\mathrm{BSH}$
2000) suggests that larval dispersal over tens of $\mathrm{km}$ per week should be rather common. Therefore, the need to study far larger spatial scales than has hitherto been done is expected to hold true even if the estimated $15000 \mathrm{~km}^{2}$ for E. americanus may be too high. However, because of the usual limitations of resources, sampling of a sufficiently large area may be beyond the capacity of any single institute. Comparable problems in sizing fish populations have been overcome by internationally coordinated programs over decades, e.g., the ICES International Bottom Trawl Surveys.

A similar network of institutes engaged in the study of benthic population or community dynamics in the continental North Sea is proposed. During the past decades this has been done several times; however, only during limited periods and for a restricted purpose (e.g., the ICES North Sea benthos survey in 1986, Künitzer et al. 1992, Basford et al. 1993). What is needed in the future is some permanent collaboration of institutes with standardised sampling programs. As an example, existing monitoring programs could be replaced by standardised sampling of some transects perpendicular to the coastline. Assuming a distance between transects of $50 \mathrm{~km}$ some 24 transects could cover the continental North Sea between the English Channel and the northern tip of Denmark. This might render satisfactory spatial resolution for some species but might be insufficient for others (e.g., Beukema et al. 1996). Alternatively, a higher number of transects might be sampled with a reduced or selective taxonomic resolution, for example by restricting the number of taxa evaluated at the species level, and centrally storing the 'rest' of the samples in case resources become available for additional analyses. Another sampling strategy might be regular zigzag cruises from the English Channel alongshore towards the Skagerrak, run by a coordinated program of the coastal states.

Acknowledgements. Sincere thanks are due to K. Reise and 4 anonymous reviewers. Their constructive remarks significantly improved the initial manuscript.

\section{LITERATURE CITED}

Adams JA (1987) The primary ecological sub-divisions of the North Sea: some aspects of their plankton communities. In: Bailey RS, Parrish BB (eds) Developments in fisheries research in Scotland. Fishing News, London, p 165-181

Armonies W (1992) Migratory rhythms of drifting juvenile molluscs in tidal waters of the Wadden Sea. Mar Ecol Prog Ser 83:197-206

Armonies W (1998) Driftendes Benthos im Wattenmeer: Spielball der Gezeitenströmungen? In: Gätje C, Reise K (eds) Ökosystem Wattenmeer: Austausch-, Transport- und Stoffumwandlungsprozesse. Springer, Berlin, p 473-498

Armonies W (2000) On the spatial scale needed for benthos 
community monitoring in the coastal North Sea. J Sea Res 43:121-133

Armonies W, Reise K (1999) On the population development of the introduced razor clam Ensis americanus near the island of Sylt (North Sea). Helgol Meeresunters 52: 291-300

Basford D, Eleftheriou A (1988) The benthic environment of the North Sea $\left(56^{\circ}\right.$ to $\left.61^{\circ} \mathrm{N}\right)$. J Mar Biol Assoc UK 68: 125-141

Basford DJ, Eleftheriou A, Davies IM, Irion G, Soltwedel T (1993) The ICES North Sea benthos survey: the sedimentary environment. ICES J Mar Sci 50:71-80

Beukema JJ (1993) Successive changes in distribution patterns as an adaptive strategy in the bivalve Macoma balthica (L.) in the Wadden Sea. Helgol Meeresunters 47: 287-304

Beukema JJ, Dekker R (1995) Dynamics and growth of a recent invader into European coastal waters: the American razor clam, Ensis directus. J Mar Biol Assoc UK 75: 351-362

Beukema JJ, Essink K (1986) Common patterns in the fluctuations of macrozoobenthic species living at different places on tidal flats in the Wadden Sea. Hydrobiologia 142:199-207

Beukema JJ, Dörjes J, Essink K (1988) Latitudinal differences in survival during a severe winter in macrozoobenthic species sensitive to low temperatures. Senckenberg Marit 20:19-30

Beukema JJ, Essink K, Michaelis H (1996) The geographic scale of synchronized fluctuation patterns in zoobenthos populations as a key to underlying factors: climatic or man-induced. ICES J Mar Sci 53:964-971

Botsford LW, Wing SR, Largier JL (1998) Population dynamics and management implications of larval dispersal. S Afr J Mar Sci 19:131-142

BSH (Bundesamt für Seeschiffahrt und Hydrographie) (2000) Current predictions of the Operational Model System of the BSH. Federal Maritime and Hydrographic Agency (BSH) at http://www.bsh.de/aktdat/modell/stroemungen/ Modell1.htm

Cadée GC (1968) Molluscan biocoenoses and thanatocoenoses in the Ria de Arosa, Galicia, Spain. Zool Verh Leiden 95:3-121

Dyer MF, Fry WG, Fry PD, Cranmer GJ (1983) Benthic regions within the North Sea. J Mar Biol Assoc UK 63: $683-693$

Essink K (1985) On the occurrence of the American jack-knife clam Ensis directus (Conrad, 1843) (Bivalvia, Cultellidae) in the Dutch Wadden Sea. Basteria 49:73-80

Essink K (1986) Note on the distribution of the American jackknife clam Ensis directus (Conrad, 1843) in N.W. Europe (Bivalvia, Cultellidae). Basteria 50:33-34

Flach EC, Beukema JJ (1994) Density-governing mechanisms in populations of the lugworm Arenicola marina on tidal flats. Mar Ecol Prog Ser 115:139-149

Gaylord B, Gaines SD (2000) Temperature or transport? Range limits in marine species mediated solely by flow. Am Nat 155:769-789

Glémarec M (1973) The benthic communities of the European North Atlantic continental shelf. Oceanogr Mar Biol Annu Rev 11:263-289

Hanski I (1999) Metapopulation ecology. Oxford Univ Press, Oxford, p 1-313

Hickel W, Bauernfeind E, Niermann U, von Westernhagen $\mathrm{H}$ (1989) Oxygen deficiency in the south-eastern North Sea: sources and biological effects. Ber Biol Anstalt Helgoland $4: 1-148$
Hill AE (1991) Vertical migration in tidal currents. Mar Ecol Prog Ser 75:39-54

Janssen GM, Kuipers BR (1980) On tidal migration in the shrimp Crangon crangon. Neth J Sea Res 14:339-348

Kendall BE, Bjørnstad ON, Bascompte J, Keitt TH, Fagan WF (2000) Dispersal, environmental correlation, and spatial synchrony in population dynamics. Am Nat 155: 628-636

Kuipers BR (1977) On the ecology of juvenile plaice on a tidal flat in the Wadden Sea. Neth J Sea Res 11:56-91

Künitzer A, Basford D, Craeymeersch JA, Dewarumez JM, Dörjes J, Duineveld GCA, Eleftheriou A, Heip C, Herman P, Kingston P, Niermann U, Rachor E, Rumohr H, de Wilde PAJ (1992) The benthic infauna of the North Sea: species distribution and assemblages. ICES J Mar Sci 49: $127-143$

Loosanov VL, Davies HC (1963) Rearing of bivalve molluscs. In: Russel FS (ed) Advances in marine biology. Academic, London, p 1-136

McQuaid CD, Phillips TE (2000) Limited wind-driven dispersal of intertidal mussel larvae: in situ evidence from the plankton and the spread of the invasive species Mytilus galloprovincialis in South Africa. Mar Ecol Prog Ser 201: 211-220

Mileikovsky SA (1968) Some common features in the drift of pelagic larvae and juvenile stages of bottom invertebrates with marine currents in temperate regions. Sarsia 34: 209-216

Möbius K (1877) Die Auster und die Austernwirtschaft. Wiegandt, Hempel und Parey, Berlin

Mühlenhardt-Siegel U, Dörjes J, von Cosel R (1983) Die amerikanische Schwertmuschel Ensis directus (Conrad) in der Deutschen Bucht. II. Populationsdynamik. Senckenberg Marit 15:93-110

Niermann U (1997) Macrobenthos of the south-eastern North Sea during 1983-1988. Ber Biol Anst Helgoland 13:1-144

Odum EP (1971) Fundamentals of ecology, 3rd edn. Saunders, Philadelphia

Olivier F, Retière C (1998) The role of physical-biological coupling in the benthic boundary layer under megatidal conditions: the case of the dominant species of the Abra alba community in the eastern Baie de Seine (English Channel). Estuaries 21:571-584

Ray C, Hastings A (1996) Density dependence: are we searching at the wrong spatial scale? J Anim Ecol 65:556-566

Salzwedel H, Rachor E, Gerdes D (1985) Benthic macrofauna communities in the German Bight. Ver Inst Meeresforsch Bremerh 20:199-267

Scheltema RS (1986) On dispersal and planktonic larvae of benthic invertebrates: an eclectic overview and summary of problems. Bull Mar Sci 39:290-322

Schiedek D, Zebe E (1987) Functional and environmental anaerobiosis in the razor clam Ensis directus (Mollusca: Bivalvia). Mar Biol 94:31-37

Sigurdsson JB, Titman CW, Davies PA (1976) The dispersal of young post-larval bivalve molluscs by byssus threads. Nature 262:386-387

Swennen C, Leopold MF, Stock M (1985) Notes on growth and behaviour of the American razor clam Ensis directus in the Wadden Sea and the predation on it by birds. Helgol Meeresunters 39:255-261

Theroux RB, Wigley RL (1983) Distribution and abundance of east coast bivalve molluscs based on specimens in the National Marine Fisheries Service Woods Hole collection. NOAA Technical Report NMFS SSRF-768

Thiébaut E, Dauvin JC, Wang Z (1996) Tidal transport of 
Pectinaria koreni postlarvae (Annelida: Polychaeta) in the Bay of Seine (eastern English Channel). Mar Ecol Prog Ser 138:63-70

Thomas CD, Kunin WE (1999) The spatial structure of populations. J Anim Ecol 68:647-657

Thorson G (1961) Length of pelagic larval life in marine bottom invertebrates as related to larval transport by ocean currents. Oceanography 67:455-474

Verdier-Bonnet C, Carlotti F, Rey C, Bhaud M (1997) A model of larval dispersion coupling wind-driven currents and

Editorial responsibility: Otto Kinne (Editor),

Oldendorf/Luhe, Germany vertical larval behaviour: application to the recruitment of the annelid Owenia fusiformis in Banyuls Bay, France. Mar Ecol Prog Ser 160:217-231

Von Cosel R, Dörjes J, Mühlenhardt-Siegel U (1982) Die amerikanische Schwertmuschel Ensis directus (Conrad) in der Deutschen Bucht. I. Zoogeographie und Taxonomie im Vergleich mit den einheimischen Schwertmuschel-Arten. Senckenber Marit 14:147-173

Young C, Ebert T (1996) Ecology of open populations. Oceanol Acta 19:471

Submitted: July 24, 2000; Accepted: October 18, 2000

Proofs received from author(s): November 20, 2000 